\title{
Model Matematika Infeksi Virus Hepatitis B dengan Adsorpsi
}

\author{
Lisa Risfana SARI \\ Departemen Manajemen, Universitas Internasional Semen Indonesia \\ lisa.sari@uisi.ac.id
}

\begin{abstract}
Abstrak
Infeksi Hepatitis B terus berlanjut menjadi masalah kesehatan global. Termotivasi hal tersebut, kami memperkenalkan model matematika infeksi virus Hepatitis B (VHB). Berangkat dari fakta bahwa tingkat infeksi bilinear tidak selalu benar dalam menggambarkan interaksi virus dengan sel rentan di kehidupan nyata, maka digunakan tingkat infeksi nonlinear pada model. Fase adsorpsi dalam proses infeksi virus dipertimbangkan dalam model sebagai salah satu penyebab penurunan populasi partikel virus. Pada model, populasi partikel virus dibagi menjadi dua kompartemen yaitu, virion dan kapsid intraseluler yang mengandung DNA-VHB. Populasi sel dibagi menjadi dua kompartemen yaitu, sel rentan dan sel terinfeksi. Perilaku dinamik model dianalisis dengan menentukan titik kesetimbangan bebas infeksi dan endemik, bilangan reproduksi dasar, serta kestabilan lokal dari titik kesetimbangan tersebut. Hasil analisis dan simulasi numerik menunjukkan bahwa stabilitas titik kesetimbangan bebas infeksi maupun endemik bergantung pada bilangan reproduksi dasar.

Kata kunci: adsorpsi, analisis dinamik, bilangan reproduksi dasar, model matematika, virus Hepatitis B.
\end{abstract}

\begin{abstract}
Hepatitis B infection continues to be a global health problem. Motivated with this, we introduce a mathematical model of hepatitis $B$ virus infection $(H B V)$. Based on the fact that bilinear infection rate is not always true in describing viral interactions with susceptible cells in real life, we use nonlinear infection rate on the model. The adsorption phase in the viral infection process is considered in the model as one of the causes of the population decline in viral particles. In the model, the viral particle population is divided into two compartments:, virions and intracellular capsid containing HBV-DNA. Cell population is divided into two compartments: susceptible cells and infected cells. The dynamic behavior of the model is analyzed by determining the free-infection equilibrium point and endemic equilibrium point, the basic reproduction number, and the local stability of the equilibrium points. The analysis and numerical simulation results show that the stability of the equilibriia, free-infection or endemic, depend on the basic reproduction number.

Keywords : adsorption, basic reproduction number, dynamical analysis, Hepatitis $\mathrm{B}$ virus, mathematical model.
\end{abstract}

2000 Mathematics Subject Classification: 37M99, 92D30 Received: 2017-08-28, accepted: 2017-11-20. 


\section{Pendahuluan}

Salah satu virus dengan potensi infeksi yang sangat berbahaya adalah virus Hepatitis B (VHB). Infeksi VHB dapat mengakibatkan infeksi akut hingga kronis. Meskipun infeksi akut VHB dapat memberikan dampak yang cukup parah, sebagian besar komplikasi serius yang terkait dengan infeksi VHB disebabkan oleh infeksi kronis [1]. Riset Kesehatan Dasar tahun 2013 menyatakan bahwa sekitar 7,2\% penduduk Indonesia terinfeksi HBV. Diperkirakan 18 juta orang memiliki Hepatitis B, dengan 50 \% diantaranya berpotensi kronis dan 10\% berpotensi fribosis hati yang dapat menyebabkan kanker hati [2]. Oleh karena itu, berkembang riset yang bertujuan untuk mempelajari pengendalian infeksi virus tersebut.

Model matematika telah banyak dimanfaatkan dalam mempelajari dinamika infeksi VHB. Pertama kali, model VHB dikembangkan oleh Nowak et al. pada tahun 1996 [3]. Model tersebut kemudian dikembangkan kembali oleh Min et al. [4] dengan mengubah tingkat infeksi menjadi tingkat infeksi nonlinear. Min et al. menyatakan tingkat infeksi bilinear yang berbasis hukum mass-action kurang sesuai dengan kondisi nyata. Pengembangan model dengan menggunakan tingkat infeksi nonlinear juga dipaparkan oleh Hattaf dan Yousfi [5] dan Zhang et al. [6]. Manna dan Chakrabarty [7] mengembangkan model dengan memperhatikan populasi kapsid DNA-VHB. Pengembangan tersebut didasari karena kapsid DNA-VHB, yang merupakan cikal bakal virion, juga berpengaruh dalam tercapainya infeksi akut maupun kronis.

Pada sebagian besar model VHB, termasuk model [3], [4], [5], [6], [7], tidak mencantumkan proses adsorpsi virus. Proses adsorpsi adalah proses menempelnya virus pada dinding sel, yang dilanjutkan dengan penetrasi materi genetik virus ke dalam sel. Hal ini mengakibatkan jumlah populasi virion berkurang dalam darah. Pada beberapa kasus infeksi virus, jumlah pengurangan virion dalam darah lebih banyak dibandingkan jumlah partikel virus yang terlibat dalam proses adsorpsi pada sel rentan. Oleh karena itu, adsorpsi penting untuk diperhatikan, dikarenakan dapat mempengaruhi secara langsung perilaku dinamik model, seperti yang telah dijelaskan oleh Dubey et al. [8] dan Pradeep et al. [9].

Dengan mempertimbangkan tingkat infeksi nonlinear, populasi kapsid DNA-VHB, dan adsorpsi virus, diperkenalkan modifikasi model VHB berikut.

$$
\left\{\begin{array}{l}
\frac{d x(t)}{d t}=s-\mu x(t)-\frac{k x(t) v(t)}{x(t)+y(t)} \\
\frac{d y(t)}{d t}=\frac{k x(t) v(t)}{(x(t)+y(t)}-\delta y(t) \\
\frac{d z(t)}{d t}=a y(t)-(\beta+\delta) z(t) \\
\frac{d v(t)}{d t}=\beta z(t)-c v(t)-\frac{k x(t) v(t)}{(x(t)+y(t)}
\end{array}\right.
$$

Pada sistem persamaan (1), fungsi $x(t), y(t), z(t)$ dan $v(t)$ mendeskripsikan kepadatan populasi sel rentan, sel terinfeksi, kapsid DNA-VHB, dan virion, terhadap satuan waktu. Laju pertumbuhan sel rentan, laju kematian alami sel rentan, dan tingkat infeksi virus, masingmasing dinyatakan oleh $s, \mu$, dan $k$. Untuk sel terinfeksi, laju kematian alami diwakili oleh $\delta$. Produksi kapsid DNA-VHB oleh sel terinfeksi dinyatakan dengan laju yaitu $a$, sedangkan transisi kapsid DNA-VHB menjadi virion dinyatakan dengan laju yaitu $\beta$. Selanjutnya, laju kematian alami virion dinotasikan dengan $c$. Melalui model tersebut dipelajari faktor-faktor yang mempengaruhi terciptanya infeksi persisten yang dapat berkembang menjadi infeksi akut bahkan kronis. Untuk mencapai hal tersebut dilakukan analisis dinamik model yang didukung dengan simulasi numerik model.

\section{Metode Penelitian}

Penelitian diawali dengan konstruksi model yang ditunjukkan oleh sistem persamaan (1). Perilaku dinamik model dianalisis dengan langkah yaitu, menentukan titik kesetimbangan bebas infeksi dan endemik; menentukan bilangan reproduksi dasar; dan menentukan kestabilan titik kesetimbangan. Setelah dianalisis, dilakukan simulasi numerik beberapa kasus untuk menggambarkan kondisi bebas infeksi maupun endemik. 
2.1. Titik Kesetimbangan. Titik kesetimbangan ditentukan dengan mencari solusi sistem persamaan saat laju pertumbuhan masing-masing subpopulasi adalah nol, seperti berikut

$$
\left\{\begin{array}{l}
s-\mu x(t)-\frac{k x(t) v(t)}{x(t)+y(t)}=0 \\
\frac{k x(t) v(t)}{(x(t)+y(t))}-\delta y(t)=0 \\
a y(t)-(\beta+\delta) z(t)=0 \\
\beta z(t)-c v(t)-\frac{k x(t) v(t)}{(x(t)+y(t))}=0
\end{array}\right.
$$

2.2. Bilangan Reproduksi Dasar. Bilangan reproduksi dasar ditentukan dengan menggunakan metode Next Generation Matrix (NGM) [10]. Langkah yang pertama adalah dengan menuliskan kembali sistem (1) menjadi sistem (3) berikut.

$$
\frac{d X}{d t}=\mathcal{F}(X)-\mathcal{V}(X)
$$

Pada sistem (3), entri vektor $\mathcal{F}(X)$ adalah laju munculnya infeksi pada kompartemen, sedangkan entri vektor $\mathcal{V}(X)$ adalah laju transfer ke kompartemen lainnya, untuk $X=(x, y, z, v)^{T}$, yang dinyatakan persamaan (4).

$$
\mathcal{F}(X)=\left[\begin{array}{c}
0 \\
\frac{k x v}{x+y} \\
a y \\
0
\end{array}\right] \text { dan } \quad \mathcal{V}(X)=\left[\begin{array}{c}
s-\mu x-\frac{k x v}{x+y} \\
\delta y \\
(\beta+\delta) z \\
\beta z=c v-\frac{k x v}{x+y}
\end{array}\right]
$$

Langkah kedua adalah menentukan matriks Jacobian dari $\mathcal{F}(X)$ dan $\mathcal{V}(X)$ pada titik kesetimbangan bebas infeksi. Misalkan $X_{0}=\left(x_{0}, y_{0}, z_{0}, v_{0}\right)$ adalah titik kesetimbangan bebas infeksi, maka matriks Jacobian dari persamaan (4) pada $X_{0}$ adalah

$$
F=\frac{\partial \mathcal{F}}{\partial X}\left(X_{0}\right) \text { dan } \quad V=\frac{\partial \mathcal{V}}{\partial X}\left(X_{0}\right)
$$

Langkah ketiga adalah menentukan bilangan reproduksi dasar yang diperoleh dari nilai eigen dominan matriks berikut

$$
N G M=F \cdot V^{-1}
$$

2.3. Kestabilan Lokal Titik Kesetimbangan. Kestabilan lokal titik kesetimbangan ditentukan berdasarkan nilai eigen atau akar persamaan karakteristik dari matriks Jacobian yang dihasilkan oleh sistem linear hampiran sistem (1) [11]. Matriks Jacobian sistem (1) dinyatakan oleh matriks berikut

$$
J=\left[\begin{array}{cccc}
-\mu-\frac{k v}{x+y}+\frac{k x v}{(x+y)^{2}} & \frac{k x v}{(x+y)^{2}} & 0 & -\frac{k x}{x+y} \\
\frac{k v}{x+y}-\frac{k x v}{(x+y)^{2}} & \frac{k x v}{(x+y)^{2}}-\delta & 0 & \frac{k x}{x+y} \\
0 & a & -\beta-\delta & 0 \\
\frac{k v}{x+y}+\frac{k x v}{(x+y)^{2}} & \frac{k x v}{(x+y)^{2}} & \beta & -c-\frac{k x}{x+y}
\end{array}\right]
$$

Menggunakan matriks (7), ditentukan persamaan karakteristik pada masing-masing titik kesetimbangan. Titik kesetimbangan dikatakan (a) stabil asimtotik lokal jika semua nilai eigen memiliki bagian real negatif, (b) stabil lokal jika semua nilai eigen memiliki bagian real tak positif, dan (c) tak stabil jika tidak memenuhi kriteria (a) dan (b). Untuk menganalisis nilai eigen digunakan Kriteria Routh Hurwitz.

Kriteria Routh-Hurwitz [12]. Misal diberikan persamaan karakteristik berderajat $n$ berikut.

$$
P(\lambda)=\lambda^{n}+A_{n-1} \lambda^{n-1}+\cdots+A_{0}=0
$$


dengan $A_{i}, i=0, . ., n-1$ bernilai real dan $A_{0} \neq 0$. Akar-akar persamaan karakteristik (8), memiliki bagian real negatif jika dan hanya jika

$$
A_{0}>0, D_{1}=\left|A_{n-1}\right|>0, D_{2}=\left|\begin{array}{cc}
A_{n-1} & A_{n-3} \\
1 & A_{n-2}
\end{array}\right|, \cdots, D_{k}=\left|\begin{array}{cccc}
A_{n-1} & A_{n-3} & \cdots & 0 \\
1 & A_{n-2} & \cdots & 0 \\
\vdots & \vdots & \ddots & \vdots \\
0 & 0 & 0 & A_{n-k}
\end{array}\right|
$$

\section{Hasil dan Pembahasan}

3.1. Titik Kesetimbangan. Berdasarkan solusi sistem (2), maka diperoleh dua titik kesetimbangan sistem (1) yaitu,

(1) Titik kesetimbangan bebas infeksi, yang mewakili kondisi dimana populasi sel terinfeksi, kapsid DNA-VHB, dan virion punah.

$$
X_{0}=\left(\frac{s}{\mu}, 0,0,0\right)
$$

Titik kesetimbangan bebas infeksi selalu eksis karena setiap elemennya bernilai positif.

(2) Titik kesetimbangan endemik, mewakili kondisi berkembangnya infeksi dimana populasi sel terinfeksi, kapsid DNA-VHB, dan virion tetap bertahan.

$$
X_{1}=\left(x^{*}, y^{*}, z^{*}, v^{*}\right)
$$

dengan

$$
\begin{array}{lll}
\Delta_{1}=\beta+\delta & x^{*}=\frac{c s \Delta_{1}}{\Delta_{3}+c \mu \Delta_{1}} & z^{*}=\frac{a s \Delta_{3}}{\delta\left(\Delta_{1} \Delta_{3}+c \mu \Delta_{1}^{2}\right)} \\
\Delta_{2}=\delta \Delta_{1}(c+k) & & \\
\Delta_{3}=a k \beta-\Delta_{2} & y^{*}=\frac{s \Delta_{3}}{\delta\left(\Delta_{3}+c \mu \Delta_{1}\right)} & v^{*}=\frac{s \Delta_{3}\left(\Delta_{3}+c \delta \Delta_{1}\right)}{c k \delta \Delta_{1}\left(\Delta_{3}+c \mu \Delta_{1}\right)}
\end{array}
$$

Titik tersebut eksis jika $\Delta_{3} \geq 0$

3.2. Bilangan Reproduksi Dasar. Menggunakan persamaan (3), (4), (5), (6), dan (10), diperoleh Next Generation Matrix berikut.

$$
N G M=\left[\begin{array}{cccc}
0 & 0 & 0 & 0 \\
0 & 0 & \frac{k \beta}{(\beta+\delta)(c+k)} & -\frac{k}{c+k} \\
0 & \frac{a}{\delta} & 0 & 0 \\
0 & 0 & 0 & 0
\end{array}\right]
$$

Bilangan reproduksi dasar yang diperoleh dari matriks (12) adalah

$$
R_{0}=\frac{\sqrt{\delta(\beta+\delta)(c+k) a k \beta}}{\delta(\beta+\delta)(c+k)} \quad \text { atau } \quad R_{0}^{2}=\frac{a k \beta}{\delta(\beta+\delta)(c+k)}
$$

Analisis lebih lanjut menunjukkan bahwa $\Delta_{3}=\left(R_{0}-1\right) \Delta_{2}$. Akibatnya, $\Delta_{3} \geq 0$ jika dan hanya jika $R_{0} \geq 1$. Dengan demikian, saat $R_{0}<1$, sistem (1) hanya memiliki satu titik kesetimbangan yaitu $X_{0}$. Sementara itu, saat $R_{0} \geq 1$, sistem (1) memiliki titik kesetimbangan tambahan yaitu $X_{1}$.

3.3. Kestabilan Titik Kesetimbangan. Kestabilan masing-masing titik kesetimbangan sistem (1) dijelaskan pada Teorema 1 berikut.

Teorema 3.1. (i) Titik kesetimbangan bebas infeksi $X_{0}$ stabil asimtotik lokal jika $R_{0}<1$; (ii) Titik kesetimbangan endemik $X_{1}$ stabil asimtotik lokal jika $R_{0}>1$.

Bukti. i) Untuk titik kesetimbangan bebas infeksi $X_{0}$, persamaan karakteristik dari matriks Jacobian (7) adalah

$$
\lambda^{3}+A_{2} \lambda^{2}+A_{1} \lambda+A_{0}=0
$$


dengan

$$
\begin{aligned}
& A_{2}=2 \delta+\beta+c+k \\
& A_{1}=\beta c+k \beta+2 \delta c+a \delta k+\delta \beta+\delta^{2} \\
& A_{0}=\left(1-R_{0}^{2}\right) \delta(\beta+\delta)(c+k)
\end{aligned}
$$

Kriteria Routh-Hurwitz menyatakan akar persamaan (14) memiliki bagian real negatif jika dan hanya jika $A_{2}>0, A_{0}>0$, dan $A_{2} A_{1}-A_{0}>0$. Persamaan (14) menunjukkan bahwa, $A_{2}>0$. Sementara itu, $A_{0}>0$ jika dan hanya jika $R_{0}^{2}<1$. Dalam hal ini, $R_{0}^{2}<1$ jika dan hanya jika $R_{0}<1$. Hasil komputasi menunjukkan $A_{2} A_{1}-A_{0}>0$. Oleh karena itu, kriteria Routh-Hurwitz terpenuhi jika $R_{0}<1$. Hal ini menunjukkan titik kesetimbangan bebas infeksi stabil asimtotik lokal jika $R_{0}<1$.

(ii) Untuk titik kesetimbangan endemik $X_{1}$, diperoleh persamaan karakteristiknya adalah

$$
\lambda^{4}+B_{3} \lambda^{3}+B_{2} \lambda^{2}+B_{1} \lambda+B_{0}=0
$$

$$
\begin{aligned}
& \text { dengan } \\
& B_{3}=\frac{1}{c \Delta_{1}\left(c \delta \Delta_{1}+\Delta_{3}\right)}\left(c^{2} \delta \Delta_{1}^{2}\left(\Delta_{1}+k+\mu+c+\delta\right)+c \Delta_{1} \Delta_{3}\left(c+2 \Delta+\mu+\Delta_{1}\right)+\Delta_{3}^{2}\right) \\
& B_{2}=\frac{1}{c \Delta_{1}\left(c \delta \Delta_{1}+\Delta_{3}\right)}\left(\Delta_{3}^{2}\left(c+\delta+\Delta_{1}\right)+c \Delta_{1} \Delta_{3}\left(c \beta+3 c \Delta+2 \delta \Delta_{1}+\mu\left(c+2 \delta+\Delta_{1}\right)\right)\right. \\
& \left.+c^{2} \delta \Delta_{1}^{2}\left(\delta\left(c+k+\Delta_{1}\right)+\Delta_{1}(c+k)+\mu\left(c+k+\delta+\Delta_{1}\right)\right)\right) \\
& B_{1}=\frac{1}{c \Delta_{1}\left(c \delta \Delta_{1}+\Delta_{3}\right)}\left(\Delta_{3}^{2}\left(c \beta+2 c \Delta+\delta \Delta_{1}\right)+\Delta_{1} \Delta_{3}\left(c^{2} \beta \mu+2 c \delta \mu \Delta_{1}+3 c^{2} \delta \mu\right)+\right. \\
& \left.\Delta_{1}^{2}\left(c^{2} k \delta^{2} \mu+c^{2} \delta \Delta_{3}+c^{3} \delta^{2} \mu\right)+\Delta_{1}^{3}\left(c^{3} \delta \mu+c^{2} k \delta \mu+c^{2} \delta^{2} \mu\right)\right) \\
& B_{0}=\frac{\left(\delta\left(c \mu \Delta_{1}^{2} \Delta_{3}+\Delta_{1} \Delta_{3}\right)\right)}{\left(\Delta_{1}\left(c \delta \Delta_{1}+\Delta_{3}\right)\right)}
\end{aligned}
$$

Merujuk pada Kriteria Routh-Hurwitz, kriteria akar persamaan karakteristik (15) memiliki bagian real yang negatif adalah $A_{3}>0, A_{0}>0, A_{3} A_{2}-A_{1}>0$, dan $\left(A_{3} A_{2}-A_{1}\right) A_{1}-$ $A_{3}^{2} A_{0}>0$. Hasil analisis menunjukkan empat kriteria tersebut terpenuhi dengan syarat cukupnya adalah $\Delta_{3}>0$. Kondisi $\Delta_{3}>0$ terpenuhi jika $R_{0}>1$. Oleh karena itu, titik kesetimbangan endemik stabil asimtotik lokal dengan syarat cukup $R_{0}>1$. Teorema terbukti

3.4. Simulasi Numerik. Untuk menggambarkan kondisi tercapainya kestabilan masing-masing titik kesetimbangan, dilakukan simulasi numerik. Terdapat dua macam situasi yang disimulasikan yaitu ketika $R_{0}<1$ dan $R_{0}>1$. Digunakan dua macam nilai parameter untuk keduanya, yang kemudian disimulasikan dengan Maple.

Pada kasus pertama yaitu $R_{0}<1$ nilai parameter yang digunakan adalah $s=10, \mu=$ $0.01, k=0.0018, \delta=0.0693, a=150, \beta=0.87, c=5$. Pemilihan nilai parameter tersebut mengacu pada [7] dengan memodifikasi nilai parameter $s, k, \delta, c$. Bilangan reproduksi dasar yang diperoleh berdasarkan himpunan nilai parameter tersebut adalah $R_{0}=0.721<1$. Terdapat tiga kondisi awal yang diamati yaitu $I V_{1}=(1050 ; 1 ; 0.1 ; 1) ; I V_{2}=(900 ; 0.1 ; 0.9 ; 0.4)$ dan $I V_{3}=(1000 ; 0.4 ; 0.2 ; 0.2)$. Hasil simulasi ditunjukkan pada Gambar 1 .

Gambar 1 menunjukkan populasi sel rentan mendekati nilai setimbang yaitu 1000, sedangkan populasi sel terinfeksi, kapsid DNA-VHB dan virion mengalami kepunahan yaitu mendekati nilai setimbang 0 . Hal ini mendukung hasil analisis yang menyatakan bahwa untuk $R_{0}<1$, perilaku solusi stabil asimtotik menuju titik kesetimbangan bebas infeksi, yang pada kasus ini adalah $X_{0}=(1000 ; 0 ; 0 ; 0)$. Bilangan reproduksi dasar $R_{0}<1$, mengindikasikan jumlah ratarata produksi sel terinfeksi pada setiap proses infeksi adalah kurang dari satu. Oleh karena itu, infeksi tidak berkembang yang ditunjukkan kepunahan populasi sel terinfeksi maupun virus. 

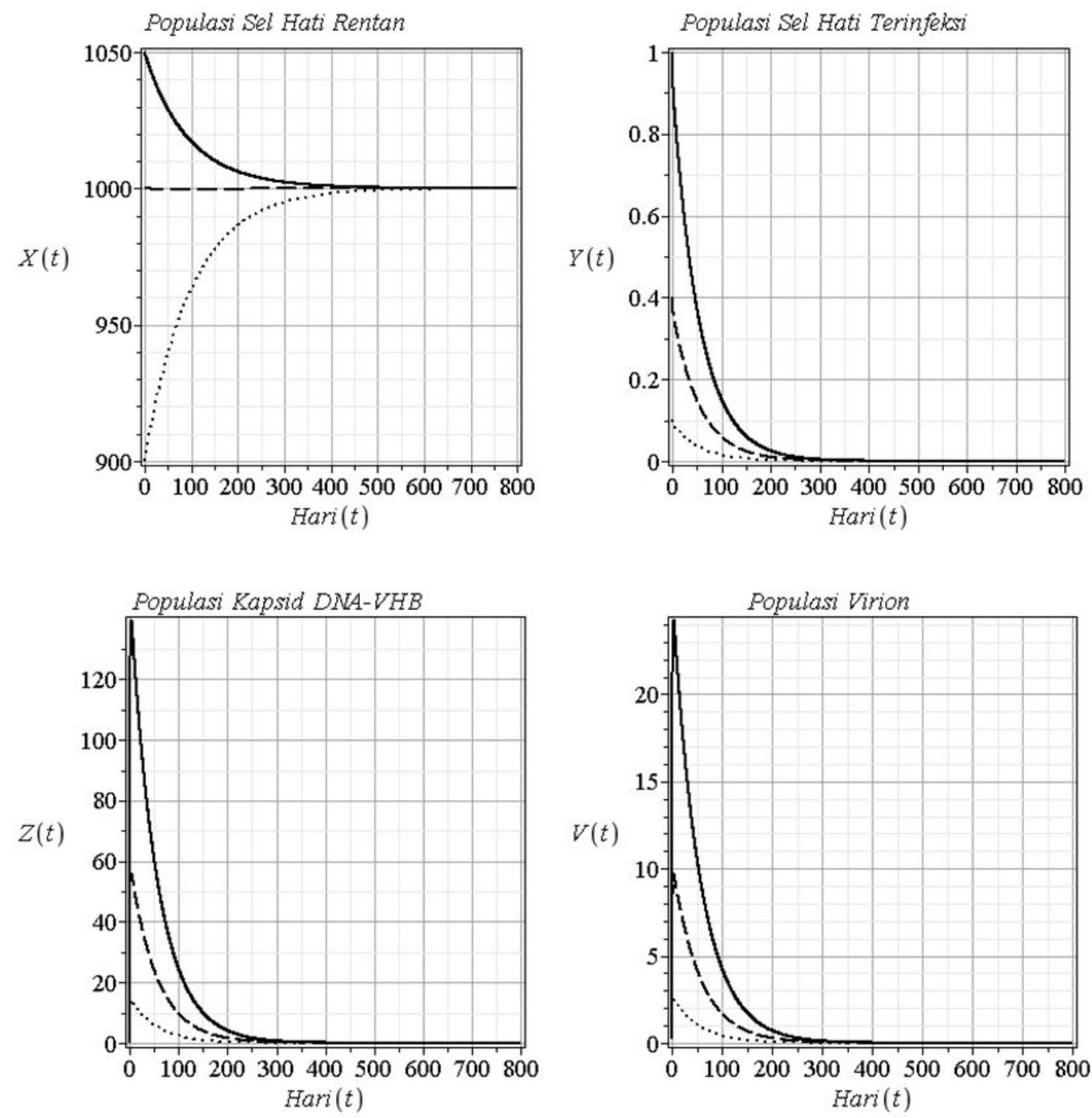

$$
-I_{1} \cdots \cdots V_{2}--V_{3}
$$

Gambar 1. Perilaku dinamik model ketika $R_{0}=0.902$ pada tiga kondisi awal $I V_{1}, I V_{2}, I V_{3}$

Simulasi kasus $R_{0}>1$, dilakukan menggunakan nilai parameter yang sama kecuali untuk $c=2$. Tiga kondisi awal yang digunakan adalah $I V_{4}=(100 ; 100 ; 10000 ; 5000), I V_{5}=$ $(200 ; 150 ; 20000 ; 7000)$, dan $I V_{6}=(300 ; 180 ; 19000 ; 9000)$. Hasil simulasi menujukkan bahwa solusi sistem mencapai kondisi setimbang, yaitu mendekati titik kesetimbangan endemik $X_{1}=$ $152.3 ; 122.3 ; 19535.2 ; 8493.5)$, seperti pada Gambar 2.

Perilaku solusi tersebut mendukung hasil analisis yang menyebutkan bahwa untuk $R_{0}>1$ solusi sistem stabil asimtotik menuju titik kesetimbangan endemik. Kondisi ini menggambarkan bahwa infeksi berlanjut dan berkembang sehingga populasi sel terinfeksi maupun virus mampu bertahan. Hal ini diakibatkan karena rata-rata jumlah sel terinfeksi lebih besar dari satu pada setiap periode infeksi, sehingga infeksi persisten terjadi. Infeksi persisten dapat berdampak menjadi infeksi akut maupun kronis.

Kedua hasil simulasi pada Gambar 1 dan Gambar 2 menunjukkan $R_{0}$ sebagai batas ambang infeksi. Dalam pengendalian infeksi yang bertujuan untuk menghambat perkembangan 

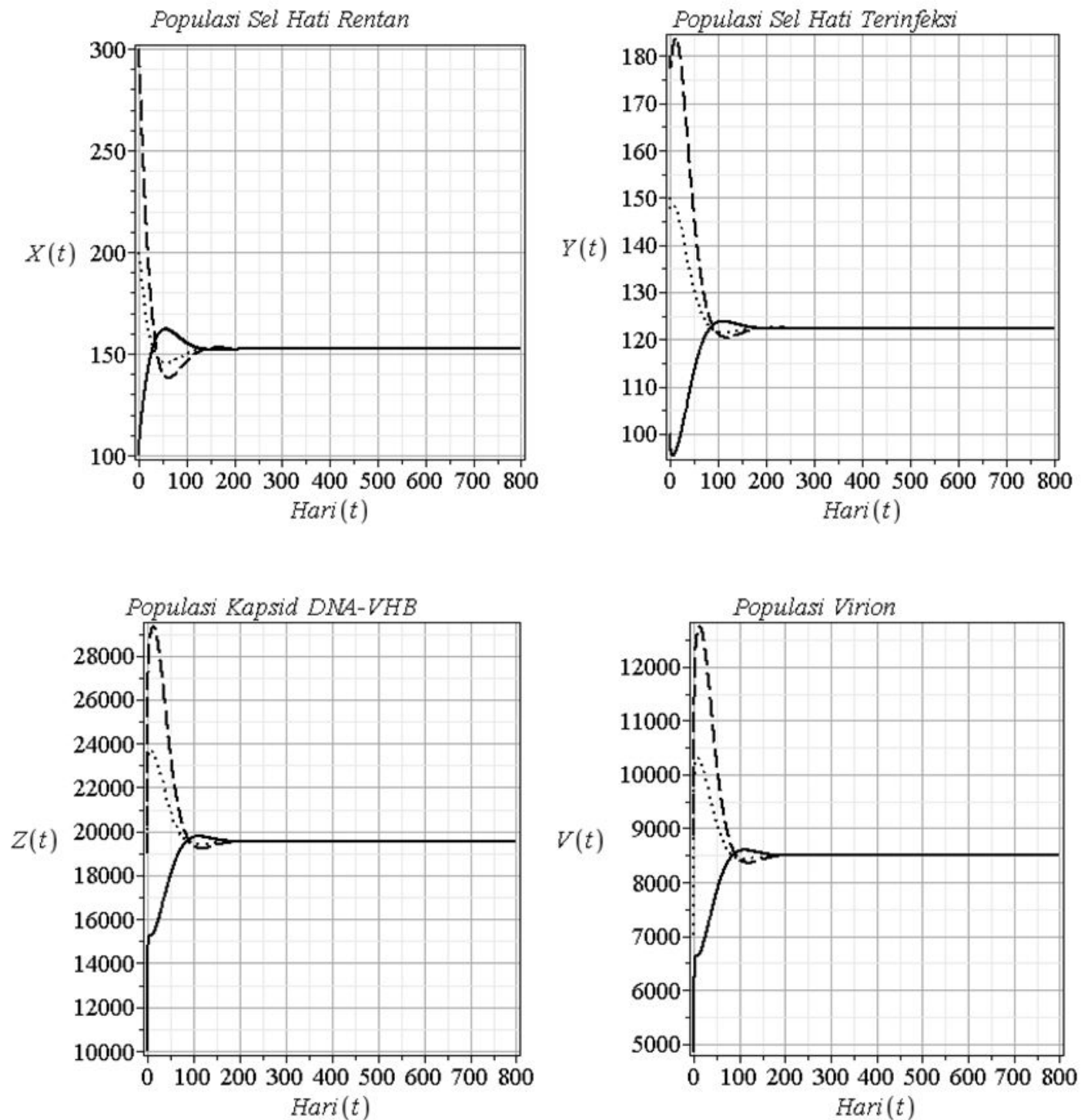

$$
-I_{4} \cdots \cdots V_{5}--I_{6}
$$

Gambar 2. Perilaku dinamik model ketika $R_{0}=1.802$ pada tiga kondisi awal $I V_{4}, I V_{5}, I V_{6}$

infeksi menjadi akut maupun kronis, penentuan batas ambang infeksi sangat diperlukan. Seperti yang ditunjukkan oleh persamaan (13), bilangan reproduksi dasar bergantung pada parameter $a, \delta, c, k$, dan $\beta$. Masing-masing parameter merepresentasikan laju produksi kapsid DNAVHB, laju kematian alami sel terinfeksi, laju kematian alami virion, tingkat infeksi, dan laju transisi kapsid DNA-VHB menjadi virion. Berdasarkan persamaan (13), dapat diketahui bahwa parameter a berpengaruh positif terhadap nilai $R_{0}$, sebaliknya $\delta$ dan $c$ berpengaruh negatif terhadap nilai $R_{0}$. Sementara itu, untuk mengetahui apakah parameter $k$ dan $\beta$ memiliki pengaruh positif atau negatif terhadap $R_{0}$, dilakukan analisis sensitivitas.

Himpunan nilai parameter $\delta=0.0693, a=150$, dan $c=2$ digunakan dalam simulasi analisis sensitivitas. Berdasarkan hasil analisis seperti pada Gambar 3, kenaikan nilai parameter $k$ maupun $\beta$ mengakibatkan kenaikan nilai $R_{0}$, atau dengan kata lain masing-masing parameter tersebut berpengaruh positif terhadap $R_{0}$. 


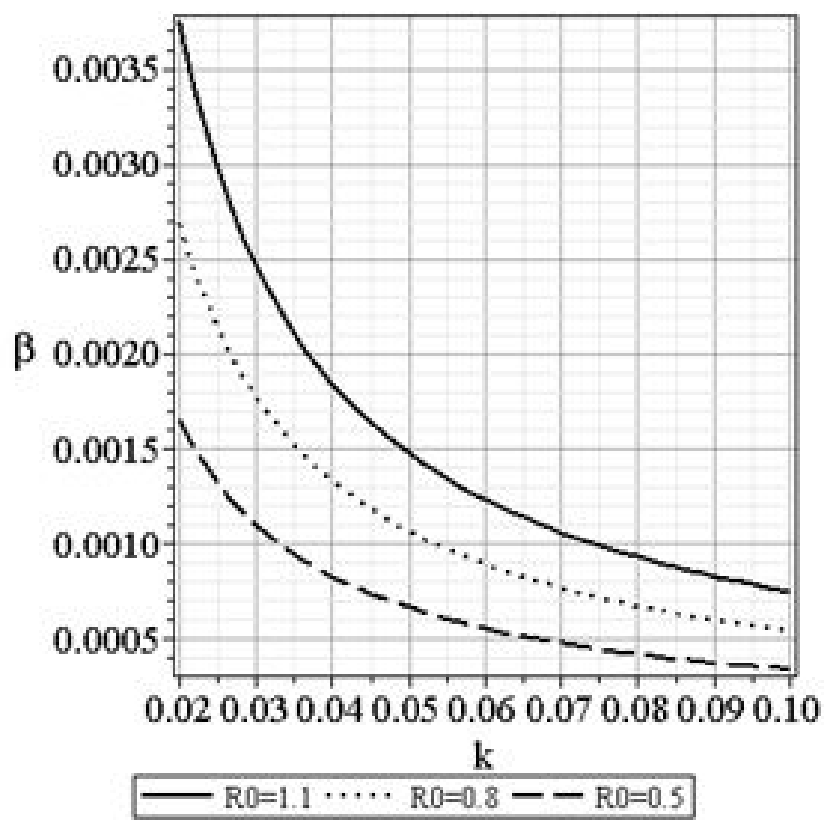

GAMBAR 3. Kaitan antara $R_{0}$ dengan tingkat infeksi $k$ dan laju transisi kapsid DNA-VHB menjadi virion $\beta$

Apabila dikaitkan dengan upaya pengendalian infeksi, hasil analisis maupun simulasi mampu menunjukkan faktor yang memicu perkembangan infeksi, diantaranya yaitu tingkat infeksi tinggi, laju produksi virion yang meningkat, serta laju kematian sel terinfeksi maupun virion yang rendah.

\section{Simpulan}

Pada penelitian ini dihasilkan modifikasi model infeksi virus Hepatitis B dengan mempertimbangan adsorpsi virus dan tingkat kejadian infeksi standar. Model memiliki dua titik kesetimbangan yaitu titik kesetimbangan bebas infeksi dan endemik. Hasil analisis maupun simulasi menunjukkan bilangan reproduksi dasar merupakan batas ambang syarat kestabilan masing-masing titik kesetimbangan. Titik kesetimbangan bebas infeksi stabil asimtotik lokal jika $R_{0}<1$, sedangkan ketika $R_{0}>1$ titik kesetimbangan endemik akan eksis dan bersifat stabil asimtotik lokal. Bilangan reproduksi dasar yang dihasilkan dari model menunjukkan faktor pendukung maupun penghambat perkembangan infeksi. Dengan merujuk pada hasil tersebut diharapkan dapat dipelajari lebih lanjut upaya penyembuhan infeksi melalui pengendalian perkembangan infeksi.

\section{DAFtar Pustaka}

[1] U.S. Department of Health \& Human Service, "Epidemiologi and Prevention of Vaccine-Preventable Disease," 16 March 2017. [Online]. Available: https://www.cdc.gov/vaccines/pubs/pinkbook/hepb.html.

[2] Kementerian Kesehatan Republik Indonesia, "SEBAGIAN BESAR KEMATIAN AKIBAT HEPATITIS VIRUS BERHUBUNGAN DENGAN HEPATITIS B DAN C KRONIS," 26 April 2016. [Online]. Available: http://www.depkes.go.id/article/view/16042700001/sebagian-besar-kematian-akibat-hepatitis-virusberhubungan-dengan-hepatitis-b-dan-c-kronis.html. 
[3] M. A. Nowak, S. Bonhoeffer, A. M. Hill, R. Boehme and H. C. Thomas, "Viral dynamics in hepatitis B virus infection," Proceedings of the National Academy of Sciences of the, vol. 93, pp. 4398-4402, 1996.

[4] L. Min, Y. Su and Y. Kuang, "Mathematical Analysis of a Basic Model of Virus Infection with Application to HBV Infection," Rocky Mountain Journal of Mathematics, vol. 38, pp. 1573-1585, 2008.

[5] K. Hattaf and N. Yousfi, "A generalized HBV model with diffusion and two delays," Computers and Mathematics with Applications, vol. 69, no. 1, pp. 31-40, 2015.

[6] T. Zhang, K. Wang and X. Zhang, "Modeling and Analyzing the Transmission Dynamics of HBV Epidemic in Xinjiang, China," Plos One, vol. 10, 2015.

[7] K. Manna and S. P. Chakrabarty, "Chronic hepatitis B infection and HBV DNA-containing capsids:Modeling and analysis," Communication in Nonlinear Science and Numerical Simulation, vol. 22, pp. 383-395, 2015.

[8] B. Dubey, P. Dubey and U. S. Dubey, "Modeling The Intracellular Pathogen-Immune Interaction with Cure Rate," Communications in Nonlinear Science and Numerical Simulation, vol. 38, pp. 72-90, 2016.

[9] B. S. A. Pradeep, W. Ma and S. Guo, "Stability properties of a delayed HIV model with nonlinear functional," J.Natn.Sci.Foundation Sri Lanka, vol. 43, no. 3, pp. 235-245, 2015.

[10] O. Diekmann, J. Heesterbeek and M. Roberts, "The construction of next-generation matrices for compartmental epidemic models," J. R. Soc. Interface, vol. 7, no. 47, p. 873885, 2010.

[11] W. E. Boyce and R. C. Diprima, Elementary Differential Equation and Boundary Value Problems, New York.: John Willey and Sons, Inc., 2012.

[12] J. D. Murray, Mathematical Biology: An Introduction, Berlin: Springer-Verlag, Inc, 2002. 
